\title{
Persepsi Generasi Milenial terhadap Model Pendidikan Islam Berbasis Keterampilan Abad 21
}

\author{
Nur Alim ${ }^{1}$, Isnada Waris Tasrim², Syahrul ${ }^{3}$ \\ ${ }^{1}$ Institut Agama Islam Negeri (IAIN) Kendari \\ Email: nuralimbasri@gmail.com \\ ${ }^{2}$ Universitas Halu Oleo (UHO) Kendari \\ Email: isnadawt@uho.ac.id \\ ${ }^{3}$ Institut Agama Islam Negeri (IAIN) Kendari \\ Email: syahrul@iainkendari.ac.id
}

\begin{abstract}
Abstrak
Penelitian ini bertujuan untuk mendeskripsikan persepsi generasi milenial terhadap model pendidikan Islam berbasis keterampilan abad 21. Penelitian ini menggunakan rancangan penelitian deskriptif kualitatif, yang dilakukan pada mahasiswa angkatan 2018 yang lahir pada kurun waktu antara 2000 - 2001 dari 9 program studi di IAIN Kendari, berjumlah 40 partisipan yang dipilih dengan metode purposive sampling. Data penelitian dikumpulkan melalui kuesioner, yang dianalisis secara kualitatif dan dilaporkan secara deskriptif. Temuan penelitian menunjukkan bahwa secara umum partisipan sebagai generasi milenial memiliki persepsi positif terhadap model pendidikan Islam berbasis keterampilan abad 21 . Mereka berpendapat bahwa model pendidikan Islam berbasis keterampilan abad 21 belum sepenuhnya terlaksana disebabkan oleh faktor ketersediaan fasilitas dan kompetensi tenaga pendidik yang belum sesuai yang diharapkan, sehingga beragam upaya yang mereka lakukan untuk menguasai keterampilan tersebut. Untuk itu direkomendasikan kepada guru dan dosen untuk memperkaya proses pembelajaran dengan berbagai kegiatan yang mengasah 4 keterampilan abad 21 agar mereka lebih terlatih dan ketersediaan fasilitas penunjang perlu mendapatkan prioritas.
\end{abstract}

Kata Kunci: Generasi milenial, model pendidikan Islam, keterampilan abad 21 


\title{
Millennial Generation's Perception of the 21st Century Skill- Based Islamic Education Model
}

\author{
Nur Alim ${ }^{1}$, Isnada Waris Tasrim², Syahrul ${ }^{3}$ \\ ${ }^{1}$ Institut Agama Islam Negeri (IAIN) Kendari \\ Email: nuralimbasri@gmail.com \\ ${ }^{2}$ Universitas Halu Oleo (UHO) Kendari \\ Email: isnadawt@uho.ac.id \\ ${ }^{3}$ Institut Agama Islam Negeri (IAIN) Kendari \\ Email: syahrul@iainkendari.ac.id
}

\begin{abstract}
This study aims to describe the millennial generation's perception of the 21st century skills-based Islamic education model. This study uses a qualitative descriptive research design, which was conducted on 2018 students who were born between 2000 - 2001 from 9 study programs at IAIN Kendari, totaling 40 participants were selected by purposive sampling method. Research data were collected through questionnaires, which were analyzed qualitatively and reported descriptively. Research findings indicate that in general, participants as millennials have a positive perception of the 21st century skills-based Islamic education model. They argue that the $21 \mathrm{st}$ century skills-based Islamic education model has not been fully implemented due to the availability of facilities and the competence of educators who are not as expected, so that various efforts are made to master these skills. For this reason, it is recommended for teachers and lecturers to enrich the learning process with various activities that hone 421 st century skills so that they are more trained and the availability of supporting facilities needs to be prioritized.
\end{abstract}

Keywords: Millennial generation, Islamic education model, 21st century skills 


\section{Pendahuluan}

The Pew Research Center melaporkan penelitian yang berjudul "Millennials: A Portrait of Generation Next" yang menyatakan bahwa suatu generasi, sebagaimana orang-rang pada umumnya, memiliki kepribadian, dan pemuda milenial telah mulai menempa kepribadiannya yang meliputi: memiliki rasa percaya diri, aktualisasi diri, liberal, bergembira dan terbuka untuk perubahan. Mereka lebih optimis daripada orangtua mereka tentang masa depan ekonomi mereka dan masa depan seluruh bangsa dan negaranya (Center, 2010). Di sisi lain, McGovern membuktikan tentang sikap generasi milenial yaitu fleksibel dan terkendali. Lebih dari apapun, kaum milenial mereka yang lahir di awal tahun 1980an sampai awal 2000an - ingin mengontrol kehidupan mereka, sehingga tugas dari orang tua, kepala sekolah dan guru adalah membangun dan menyediakan perangkat agar mereka dapat mengendalikan kehidupan mereka (McGovern, 2017).

Milenial tidak sekedar sebuah generasi melainkan sikap untuk melintasi berbagai generasi. Menurut the US Census Population Survey, kaum milenial sangat terdidik dan memiliki koneksi yang jauh lebih baik. Mereka sangat kuat, kurang religius, lebih lambat menikah dan memiliki lebih sedikit keturunan ketika mereka menikah. Mereka seoptimis generasi sebelum mereka. Mereka tidak memandang merek (brands) atau institusi atau tokoh-tokoh boneka. Mereka mengetahui bahwa masa depan harus mereka bangun sendiri bersama teman dan kolega mereka. Mereka juga memahami bahwa mereka harus mengendalikan karir mereka sendiri. Oleh karenanya, mereka harus berpikir secara mandiri. Kerja seumur hidup adalah dongeng bagi mereka, akan tetapi segala sesuatunya merupakan pembelajaran sepanjang hidup, bergerak dalam kendali. Mereka menyadari bahwa mereka hidup di dunia digital yang tidak permanen dan selalu berubah serta mereka tidak akan melakukan atau membeli kebohongan (Hanna at al, 2019).

Penerapan keterampilan abad 21 (21st century skills) dalam dunia pendidikan sangat urgen karena keterampilan abad 21 dibutuhkan oleh generasi milenial dalam menghadapi tantangan di masa depan dengan penuh keberanian dan percaya diri. Penerapan dan penguasaan terhadap keterampilan abad 21 merupakan aspek penting yang menandai transformasi pendidikan dari abad 20 menuju abad 21. Oleh karena itu, pendidikan Islam semestinya membekali generasi milenial dengan keterampilan abad 21 yang meliputi keterampilan 
pemecahan masalah, keterampilan teknologi, keterampilan dasar, keterampilan berkomunikasi, keterampilan berfikir kritis dan kreatif, keterampilan penalaran, keterampilan interpersonal, keterampilan multibudaya dan bahasa serta informasi dan literasi digital. Semua keterampilan tersebut dibutuhkan oleh generasi milenial untuk menghadapi masa depan tanpa rasa takut. Untuk memastikan bahwa model pendidikan Islam berbasis keterampilan abad 21 telah dipahami dan bahkan dibutuhkan oleh generasi milenial, maka penelitian ini bertujuan untuk mengkaji persepsi generasi milenial terhadap model pendidikan Islam berbasis keterampilan abad 21. Kajian ini dipandang penting karena masih sangat sedikit ditemukan penelitian terdahulu yang secara spesifik mengkaji topik serupa dengan kajian dalam penelitian ini, sehingga hasil penelitian ini diharapkan bermanfaat bagi dunia pendidikan Islam khususnya agar lembaga-lembaga Islam lebih mempersiapkan diri untuk meningkatkan dan membenahi praktik pendidikan yang disesuaikan dengan kebutuhan peserta didik di abad 21 ini. Sebagaimana Hadits Rosulullah SAW menyatakan: "Didiklah anak-anakmu sesuai dengan zamannya".

\section{Metode}

Penelitian ini menggunakan rancangan penelitian deskriptif kualitatif yang akan memaparkan tentang persepsi generasi milenial terhadap model pendidikan Islam berbasis keterampilan abad 21 . Subyek dari penelitian ini adalah mahasiswa angkatan 2017 dari 9 program studi di IAIN Kendari berjumlah 40 partisipan yang memenuhi kriteria sebagai generasi milenial yang dipilih dengan metode purposive sampling artinya partisipan ditentukan berdasarkan pertimbangan bahwa semua partisipan yang menjadi subyek dari penelitian ini adalah mereka yang termasuk dalam kategori generasi milenial yaitu generasi yang dilahirkan pada kurun waktu 1999 - 2000 an. Data penelitian dikumpulkan melalui kuesioner dengan 2 model yaitu angket terbuka dan tertutup. Untuk kuesioner tertutup, partisipan memilih 4 jawaban yang sesuai dengan pendapat mereka, yaitu: sangat setuju, setuju, tidak setuju, dan sangat tidak setuju, sementara untuk kuesioner terbuka, partisipan diminta untuk mengemukakan pendapat mereka secara tertulis tentang upaya-upaya yang dilakukan untuk menguasai keterampilan abad 21 dan pandangan mereka terhadap model pendidikan Islam yang diterapkan dewasa ini. Untuk memperoleh temuan yang sesuai dengan tujuan penelitian ini, maka 
data dianalisis menggunakan 3 langkah sebagaimana yang diusulkan oleh Miles dan Huberman (1994) dan Sugiyono (2014) yaitu reduksi data, penyajian data, dan verifikasi atau penarikan kesimpulan. Selanjutnya data yang telah dianalisis disusun berdasarkan kategorikategori sesuai topik penelitian dan dilaporkan secara deskriptif kualitatif pula yaitu dalam bentuk uraian dan penjelasan terkait persepsi partisipan sebagai bagian dari generasi milenial terhadap model pendidikan Islam berbasis keterampilan abad 21 .

\section{Hasil Penelitian}

Penelitian ini bertujuan untuk mendeskripsikan persepsi generasi milenial terhadap model pendidikan Islam berbasis keterampilan abad 21. Pengumpulan data dilakukan dengan dua cara yakni melalui angket tertutup dan terbuka. Berikut ini akan disajikan hasil analisis data yang diperoleh melalui angket tertutup berkaitan dengan persepsi generasi milenial terhadap model pendidikan yang berbasis keterampilan abad 21 yang meliputi 4 keterampilan, yaitu: keterampilan komunikasi, kolaborasi, berfikir kritis dan pemecahan masalah serta berfikir kreatif dan inovatif.

Tabel 1: Hasil Analisis Data dari Angket Tertutup

\begin{tabular}{|c|c|c|c|c|c|c|c|c|c|c|c|}
\hline \multirow{3}{*}{$\begin{array}{l}\mathrm{N} \\
\mathrm{o}\end{array}$} & \multirow{3}{*}{$\begin{array}{l}\text { Keterampilan } \\
\quad \text { Abad } 21\end{array}$} & \multicolumn{8}{|c|}{ Skala } & \multirow{2}{*}{\multicolumn{2}{|c|}{ Total }} \\
\hline & & \multicolumn{2}{|c|}{$\begin{array}{l}\text { Sangat } \\
\text { setuju }\end{array}$} & \multicolumn{2}{|c|}{ Setuju } & \multicolumn{2}{|c|}{$\begin{array}{l}\text { Tidak } \\
\text { setuju }\end{array}$} & \multicolumn{2}{|c|}{$\begin{array}{c}\text { Sangat } \\
\text { tidak } \\
\text { setuju }\end{array}$} & & \\
\hline & & $\mathrm{N}$ & $\%$ & $\mathrm{~N}$ & $\%$ & $\mathrm{~N}$ & $\%$ & $\mathrm{~N}$ & $\%$ & $\mathrm{~N}$ & $\%$ \\
\hline 1 & Komunikasi & 16 & 40 & 23 & 57 & 1 & 3 & 0 & 0 & 40 & 100 \\
\hline 2 & Kolaborasi & 13 & 33 & 25 & 62 & 2 & 5 & 0 & 0 & 40 & 100 \\
\hline 3 & $\begin{array}{l}\text { Berfikir kritis dan } \\
\text { Pemecahan masalah }\end{array}$ & 12 & 30 & 25 & 63 & 3 & 7 & 0 & 0 & 40 & 100 \\
\hline 4 & $\begin{array}{l}\text { Berfikir kreatif dan } \\
\text { inovasi }\end{array}$ & 20 & 50 & 18 & 45 & 2 & 5 & 0 & 0 & 40 & 100 \\
\hline
\end{tabular}

Gambar 1: Rangkuman Hasil Penelitian

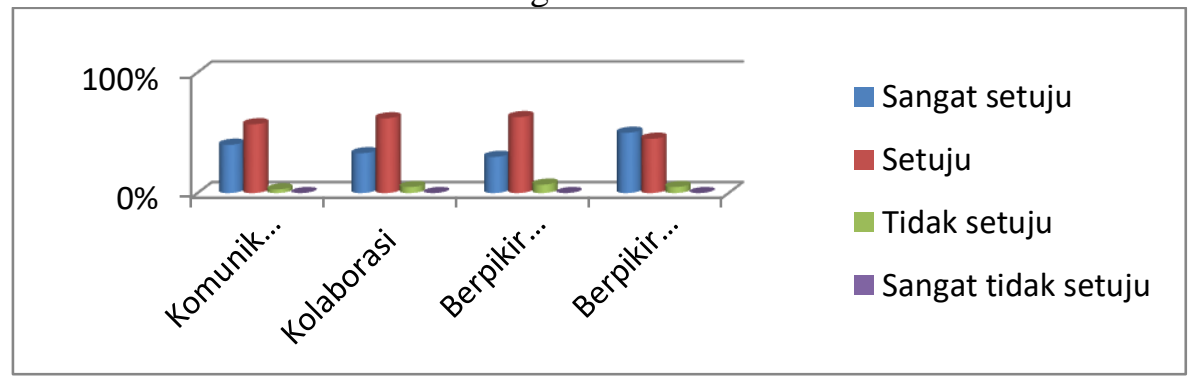


Hasil analisis data yang sajikan pada Tabel 1 dan gambar 1 menunjukkan bahwa untuk keterampilan komunikasi, sebanyak 16 orang atau $40 \%$ dari partisipan yang menyatakan sangat setuju dengan model pendidikan Islam yang melatih keterampilan komunikasi sebagai salah satu skill yang harus dimiliki oleh generasi milenial. Sementara terdapat 23 orang atau $57 \%$ partisipan memilih 'setuju'. Adapun yang menjawab tidak setuju hanya 1 orang atau $3 \%$ dari partisipan, sementara tak seorang pun yang memilih 'sangat tidak setuju'. Selanjutnya, untuk keterampilan kolaborasi terdapat 13 orang atau 33\% yang 'sangat setuju' sementara 25 orang atau $62 \%$ yang memilih 'setuju'. Adapun yang menjawab 'tidak setuju' sebanyak 2 orang atau 5\% dari total partisipan dan tidak ada partisipan yang memilih jawaban 'sangat tidak setuju'. Hasil analisis data untuk keterampilan Berfikir kritis dan pemecahan masalah sebanyak 12 orang atau $30 \%$ dari partisipan yang menyatakan 'sangat setuju' dengan model pendidikan Islam yang melatih keterampilan berfikir kritis dan pemecahan masalah sebagai salah satu skill yang harus dimiliki oleh generasi milenial. Sementara terdapat 25 orang atau $63 \%$ partisipan memilih 'setuju'. Adapun yang menjawab 'tidak setuju' 3 orang atau $7 \%$ dari partisipan, sementara tak seorang pun yang memilih 'sangat tidak setuju'. Selanjutnya, untuk keterampilan berfikir kreatif dan inovasi terdapat 20 orang atau 50\% yang 'sangat setuju' sementara 18 orang atau $45 \%$ yang memilih 'setuju'. Adapun yang menjawab 'tidak setuju' sebanyak 2 orang atau $5 \%$ dari total partisipan dan tidak ada partisipan yang memilih jawaban 'sangat tidak setuju'. Berdasarkan hasil analisis data tersebut dapat ditarik kesimpulan bahwa secara umum generasi milenial memiliki persepsi positif terhadap penerapan model pendidikan Islam berbasis keterampilan abad 21 yang meliputi keterampilan komunikasi, kolaborasi, berfikir kritis dan pemecahan masalah, serta berfikir kreatif dan inovasi.

Selanjutnya, hasil analisis data yang diperoleh dari angket terbuka yang berkaitan dengan pendapat mereka tentang model pendidikan Islam yang sudah diterapkan dewasa ini dan upaya-upaya yang dilakukan oleh generasi milenial untuk menguasai keterampilan abad 21 menunjukkan bahwa 23 orang atau lebih dari 50\% dari total partisipan berpendapat bahwa model pendidikan Islam yang diterapkan sejauh ini belum sepenuhnya berbasis keterampilan abad 21. Hal ini disebabkan oleh dua faktor, yaitu: ketersediaan fasilitas 
penunjang dan kompetensi tenaga pendidik yang belum memadai. Untuk mengimbangi kelemahan dan ketertinggalan tersebut, maka beragam upaya yang dilakukan oleh partisipan sebagai bagian dari generasi milenial, yaitu: belajar dengan sungguh-sungguh dengan meningkatkan pemahaman terhadap ilmu pengetahuan dan temuantemuan baru dalam bidang teknologi dan berusaha untuk menggunakan teknologi secara cerdas untuk membantu menyelesaikan tugas-tugas kuliah, melibatkan diri dalam berbagai kegiatan organisasi baik di dalam maupun di luar kampus untuk mengasah keterampilan komunikasi dan kolaborasi, serta berupaya aktif melakukan penelitian untuk mengasah kompetensi berfikir kritis, kreatif, inovatif dan pemecahan masalah.

\section{Pembahasan}

\section{A. Karakteristik Generasi Milenial dalam Akses Pendidikan}

Karakteristik generasi milenial di Indonesia meliputi beberapa kriteria sebagai berikut: (1) Secara psikologis, generasi milenial merupakan generasi yang percaya diri, ekspresif, memiliki harga diri yang sangat tinggi akan tetapi memiliki kepribadian yang kurang matang; (2) Mereka memiliki tingkat kepercayaan yang rendah terhadap informasi yang disampaikan secara konvensional; (3) Milenial lebih dominan menggunakan media sosial sebagai pusat informasi dan komunikasi; (4) Milenial memiliki minat yang rendah terhadap kegiatan membaca secara konvensional, mereka lebih tertarik untuk membaca secara elektronik melalui gadget, smartphone, laptop atau computer. Sumber informasi bagi milenial ada pada smartphone mereka; (5) Milenial juga sangat responsive dan terbuka terhadap perkembangan ilmu pengetahuan dan teknologi; (6) Milenial lebih tertarik menggunakan cara-cara instan untuk melakukan sesuatu; (7) Milenial kurang tertarik dalam merespon isu-isu politik yang timbul di lingkungan mereka; (8) Pada sisi lain, generasi milenial mengalami kemunduran nilai-nilai moral dan sosial; dan (9) generasi milenial juga dipandang sebagai seseorang yang malas, manja, egois dan memiliki perilaku instan yang merupakan sikap-sikap yang melekat pada mayoritas generasi milenial saat ini (Hanna at al, 2019).

Berdasarkan semua karakteristik tersebut, nampak bahwa generasi milenial dengan segala dinamikanya memiliki kelebihan dan kekurangan. Untuk memaksimalkan kekuatan atau kelebihan generasi milenial, sekolah memiliki tanggung jawab untuk mempersiapkan 
mereka sehingga dapat menjadi generasi milenial yang dapat beradaptasi bahkan mempengaruhi perubahan dan perkembangan ilmu pengetahuan dan teknologi secara positif dan cerdas. Demikian pula, kelemahan mereka khususnya pada aspek nilai-nilai moral dan sosial juga menjadi tugas sekolah untuk membina dan menyadarkan mereka sehingga mereka dapat memiliki karakter yang baik untuk dapat beradaptasi dengan perubahan-perubahan dan berani mempertaruhkan nilai-nilai yang baik secara konvensional.

Perubahan radikal dalam berbagai aspek kehidupan masyarakat dewasa ini membutuhkan perhatian yang cermat oleh para pelaku dan pengambil keputusan dan kebijakan. Kesalahan menilai, menyusun, dan mengembangkan kebijakan akan berakibat fatal terhadap laju pertumbuhan sebuah negara. Dari seluruh komponen dan aspek pertumbuhan yang ada, manusia merupakan faktor yang terpenting karena merupakan pelaku utama dari berbagai proses dan aktivitas kehidupan. Oleh karena itu, berbagai negara di dunia berusaha untuk mendefinisikan karakteristik manusia abad 21 yang dimaksud. Berdasarkan "21stCentury Partnership Learning Framework", terdapat beberapa kompetensi dan/atau keahlian yang harus dimiliki oleh SDM abad 21 (Robinson \& Kay, 2010), yaitu:

1. Kemampaun berpikir kritis dan pemecahan masalah (CriticalThinking and Problem-Solving Skills)- mampu berfikir secara kritis, lateral, dan sistemik, terutama dalam konteks pemecahan masalah

2. Kemampuan berkomunikasi dan bekerjasama (Communication and Collaboration Skills) - mampu berkomunikasi dan berkolaborasi secara efektif dengan berbagai pihak

3. Kemampuan mencipta dan membaharui (Creativity and Innovation Skills) - mampu mengembangkan kreativitas yang dimilikinya untuk menghasilkan berbagai terobosan yang inovatif

4. Kemampuan Literasi teknologi informasi dan komunikasi (Information and Communications Technology Literacy) - mampu memanfaatkan teknologi informasi dan komunikasi untuk meningkatkan kinerja dan aktivitas sehari-hari

5. Kemampuan belajar kontekstual (Contextual Learning Skills) mampu menjalani aktivitas pembelajaran mandiri yang kontekstual sebagai bagian dari pengembangan pribadi

6. Kemampuan memanfaatkan informasi dan literasi media (Information and Media Literacy Skills) - mampu memahami dan 
menggunakan berbagai media komunikasi untuk menyampaikan beragam gagasan dan melaksanakan aktivitas kolaborasi serta interaksi dengan beragam pihak.

Sejalan dengan karakteristik manusia abad 21, dalam konteks dunia pendidikan, banyak perubahan yang terjadi khususnya pada generasi milenial karena perubahan teknologi yang selalu disuguhkan pada mereka setiap hari (Brown, 2005). Perubahan-perubahan tersebut, antara lain adalah 1) Mereka menyukai adanya kontrol. Para siswa generasi abad ke-21 tidak menyukai terikat oleh jadwal-jadwal tradisional, dan juga tidak menyukai duduk di dalam kelas untuk belajar, atau duduk di dalam kantor untuk bekerja. Sebaliknya mereka lebih menyukai untuk belajar sendiri dengan menggunakan alat komunikasi yang bisa menjangkau dunia yang tak terbatas. Dengan caranya sendiri, mereka akan memperoleh informasi dari berbagai sumber di dunia. Dengan demikian, mereka harus dikontrol target pencapaian pengetahuannya, proses belajarnya dan hasil yang mereka dapatkan; 2) Mereka juga menyukai banyak pilihan. Untuk mata pelajaran project, yakni tugas melakukan mini riset, mereka akan menggunakan teknologi untuk memperoleh banyak informasi. Mereka harus diberi kebebasan untuk memilih metode dan teknik-tekniknya, untuk mereka jalani dan pada akhirnya akan mampu menyiapkan laporan, sebagaimana para siswa atau mahasiswa yang melakukannya secara tradisional; 3) Mereka adalah orang-orang yang menyukai ikatan kelompok dan ikatan sosial, hanya saja mereka membangun group melalui media sosial mereka, dan oleh karenanya kelompok mereka lintas bangsa, negara, budaya dan bahkan agama. Mereka memiliki jejaring internasional yang dinamis, dan ketika mereka menjadikan jejaringnya sebagai peer group-nya, maka mereka akan memiliki pengalaman keilmuan yang jauh lebih baik, daripada tutorial atau mentoring dalam satu kelas di sekolah tradisional; dan 4) Mereka adalah orang-orang terbuka, melalui tradisi jejaringnya mereka mengalami proses belajar untuk menjadi terbuka, karena dalam jaringannya semua penganut agama ada dan terkelompokkan, ada yang Kristen, Katholik, Hindu, Buddha dan juga Kong Hu Chu, atau bahkan mungkin ada yang atheis, tapi komunikasi mereka tetap berjalan dan tidak terganggu oleh perbedaan-perbedaan tersebut.

Anak-anak generasi milenium ke-3 ini juga memiliki beberapa perbedaan dari generasi sebelumnya. Berbagai kekhasan mereka itu adalah sebagai berikut: 1) terbiasa dengan teknologi digital; 2) berfikir 
berbeda tentang teknologi; 3) menyukai eksperimen-eksperimen dalam pemanfaatan teknologi (Jukes, 2005).

Untuk mendidik dan mempersiapkan generasi milenial sebagai penerus peradaban dunia, mereka harus memiliki tanggung jawab terhadap sustainabilitas peradaban dunia, harus mampu bekerjasama lintas bangsa, negara, budaya dan agama. Pada saat yang sama, mereka juga sudah sangat dimudahkan dengan teknologi yang ratarata orang Indonesia menghabiskan waktu 5.5 jam perhari untuk membuka dan membaca smartphone-nya (Nistanto, 2015). Meskipun, hasil survey McKinsey, memperlihatkan bahwa masyarakat Indonesia masih di bawah Singapura, Filipina dan Thailand dalam penggunaan internet, dengan hanya 34\% dari total penduduk, sementara Amerika Serikat sudah mencapai $87 \%$. Akan tetapi pengguna media sosial seperti facebook, twitter dan instagram, penetrasi masyarakat Indonesia melampaui Amerika Serikat (Fajrina, 2016). Kemudian, mereka juga harus mampu mengembangkan jejaring kerjasama antar bangsa, harus menjadi orang kreatif dan inovatif, memiliki rasa percaya diri yang baik, mampu berkomunikasi dan meyakinkan mitra kerjanya dengan baik, serta tetap memiliki patriotisme yang kuat di tengah arus globalisasi yang mempengaruhi cara berfikir masyarakat dunia hari ini dan esok.

\section{B. Persepsi terhadap Model Pendidikan Islam}

Persepsi positif generasi milenial terhadap model pendidikan Islam yang berbasis keterampilan abad 21 menurut sejumlah pakar pendidikan memang sudah semestinya karena penguasaan terhadap keterampilan abad 21 mutlak untuk diprioritaskan dan tidak dapat ditunda (Tilaar, 1997). Model pendidikan yang tidak berbasis keterampilan abad 21 tidak dapat memberi solusi atas kesenjangan tersebut, sehingga tidak dapat dihindari lagi bahwa peserta didik di sekolah maupun di perguruan tinggi harus menguasai keterampilan abad 21 sebagai bekal mereka untuk hidup dan berperan di masyarakat.

Menurut Darma, model belajar peserta didik di abad 21 sangat berbeda dengan model pembelajaran di abad 20, sehingga semua jenjang pendidikan dan para pendidik dituntut untuk dapat merancang dan melaksanakan kegiatan pembelajaran yang melatih keterampilan abad 21 bagi seluruh peserta didik. Secara perlahan, apabila peserta didik, dalam hal ini, generasi milenial telah menguasai keterampilan 
abad 21 tersebut, maka diharapkan mereka tidak akan mengalami kesulitan dalam memenuhi kebutuhan-kebutuhan mereka pada saat mereka membangun karir di dunia kerja dimanapun mereka berkiprah (Darma, 2008).

Keterampilan abad 21 ini tidak sekedar suatu kompetensi akan tetapi akan membentuk karakter peserta didik karena penguasaan terhadap keterampilan ini dilaksanakan dalam proses pembelajaran yang berpusat pada peserta didik, sehingga diharapkan peserta didik memiliki karakter yang sering disebut sebagai 4C, yaitu: (1) Communication. Pada karakter ini, peserta didik dituntut untuk memahami, mengelola, dan menciptakan komunikasi yang efektif dalam berbagai bentuk dan isi secara lisan, tulisan, dan multimedia. Peserta didik diberikan kesempatan menggunakan kemampuannya untuk mengutarakan ide-idenya, baik pada saat berdiskusi dengan teman-temannya maupun ketika menyelesaikan masalah yang ditugaskan oleh pendidiknya; (2) Collaboration. Pada karakter ini, peserta didik menunjukkan kemampuannya dalam kerjasama berkelompok dan kepemimpinan, beradaptasi dalam berbagai peran dan tanggungjawab, bekerja secara produktif dengan yang lain, menempatkan empati pada tempatnya, menghormati perspektif yang berbeda. Peserta didik juga menjalankan tanggungjawab pribadi dan fleksibitas secara pribadi, pada tempat kerja, dan hubungan masyarakat, menetapkan dan mencapai standar dan tujuan yang tinggi untuk diri sendiri dan orang lain, dan memaklumi kerancuan; (3) Critical Thinking and Problem Solving. Pada karakter ini, peserta didik berusaha untuk memberikan penalaran yang masuk akal dalam memahami dan membuat pilihan yang rumit, memahami interkoneksi antar sistem. Peserta didik juga menggunakan kemampuan yang dimilikinya untuk berusaha menyelesaikan permasalahan yang dihadapinya dengan mandiri, peserta didik juga memiliki kemampuan untuk menyusun dan mengungkapkan, menganalisis, dan menyelesaikan masalah; dan (4) Creative Thinking and Innovation. Pada karakter ini, peserta didik memiliki kemampuan untuk mengembangkan, melaksanakan, dan menyampaikan gagasan-gagasan baru kepada yang lain, bersikap terbuka dan responsif terhadap perspektif baru dan pandangan berbeda (Brown, 2005).

Berdasarkan temuan penelitian ini bahwa penerapan model pendidikan dan pembelajaran yang berbasis keterampilan abad 21 memerlukan fasilitas penunjang dan kompetensi guru sebagai 
fasilitator pembelajaran. Hal ini tentu tidak mudah disebabkan belum semua lembaga pendidikan kita memiliki fasilitas pendukung yang memadai dan para pendidik yang memiliki kompetensi memadai dalam merancang model pembelajaran yang membekali peserta didik dengan keterampilan abad 21. Mengenai hal ini, Roekel berpendapat bahwa berdasarkan hasil berbagai penelitian yang dilakukan di Amerika dalam sepuluh tahun terakhir, bahwa kehidupan manusia di dunia sekarang ini sangat kompleks dibanding dengan 50 tahun lalu, karena mobilitas antara negara yang dilakukan masyarakat dunia saat ini, interaksi sosial yang semakin mengglobal, komunikasi sosial lintas negara, bangsa, budaya dan agama dengan menggunakan media virtual yang sangat cepat, formasi pekerjaan yang terbuka sangat lebar dalam berbagai variasi formasi yang sangat dinamis (Roekel, 2012).

Berbagai tantangan dalam dunia kerja yang sudah tidak memerlukan para pekerja untuk menyelesaikan pekerjaan-pekerjaan rutinitas adminsitratif, tapi sebaliknya para pekerja profesional dituntut untuk lebih banyak melakukan innovasi dan kreatifitas dalam pengembangan bisnis, berkomunikasi dengan berbagai mitra usaha lintas negara, bangsa, budaya, agama dan bahasa. oleh sebab itulah, para siswa harus dipersiapkan dengan empat kompetensi, yaitu critical thinking, communication, collaboration, creative thinking dan innovation, Tanpa mengabaikan berbagai kompetensi lainnya, keempat kompetensi tersebut menjadi fokus yang jauh lebih kuat untuk menjadi tugas para pendidik di abad ke-21 ini. Untuk melaksanakan tugas tersebut, fasilitas penunjang berupa perangkat teknologi menjadi bagian yang sangat urgen untuk dipenuhi oleh lembaga-lembaga pendidikan saat ini, karena penguasaan teknologi menjadi bagian yang penting dari penguasaan keterampilan abad 21 oleh generasi milenial (Patimah, 2017; Nata, tanpa tahun; Sofwan \& Habibi, 2016).

Di era milenial saat ini, hampir tidak ada batas yang jelas antara bangsa satu dengan bangsa lain, peradaban satu dengan peradaban lainnya. Budaya suatu bangsa dengan budaya bangsa lainnya. Manusia bisa dengan mudah berbaur dengan manusia lain di berbagai belahan bumi ini. Aktivitas manusia yang dilakukan di benua Amerika pada detik ini, bisa diketahui bahkan diikuti oleh manusia lain yang ada di benua Asia, Eropa, Afrika maupun Australia. Kenyataan ini tentu menuntut sumber daya manusia yang mampu dengan mudah beradaptasi terhadap perubahan zaman. Sumber daya 
manusia-sumber daya manusia ini merupakan produk dari pendidikan di suatu bangsa. Apa yang dituntut dari output pendidikan di abad 21 ini adalah lulusan-lulusan yang mampu berpikir kritis, memiliki kompetensi dalam pemecahan masalah, kreatif inovatif, kompeten dalam ICT, komunikatif dan menguasai berbagai bahasa atau memiliki keterampilan multilingual. Untuk menghasilkan sumber daya manusia dengan kompetensi tersebut, lembaga pendidikan terutama guru sebagai sutradara lapangan dituntut untuk mengubah model penyelenggaraan pendidikan dengan cara yang berbeda dengan cara-cara yang selama ini telah dijalankan. Pembelajaran di era milenial menuntut peserta didik mampu berkompetisi dengan menunjukkan kompetensinya agar mereka hidup sejahtera di era global ini. Peserta didik harus lebih banyak belajar dengan cara yang berbeda baik teknik, metode, sarana dan prasarana, IT bahkan semangat dan daya juang. Pembelajaran di era global yang diharapkan adalah pembelajaran yang lebih berfokus pada peserta didik (student center), peserta didik dikondisikan untuk mampu secara aktif mencari informasi (Sofwan \& Habibi, 2016; Muslih dkk, 2013).

\section{Tuntutan Pendidikan Abad 21}

Pendidikan lebih memberikan rangsangan agar peserta didik menjadi pembelajar yang aktif, tidak pasif. Jadi pembelajaran pada abad 21 ini dikelola sedemikian rupa sehingga merangsang, mendorong dan membiasakan peserta didik agar dapat secara aktif menggali informasi dari berbagai sumber yang tersedia. Tuntutan pendidikan di era global ini menjadi tuntutan sekaligus tantangan besar bagi para guru dalam menyelenggarakan pembelajaran. Guru dipaksa untuk mampu mengimbangi tuntutan ini. Guru dituntut untuk benar-benar profesional dalam mengemban tugas dan fungsinya sebagai sosok pengajar dan pendidik dengan berbekal kompetensi paedagogik, kepribadian, sosial dan profesional secara utuh. Demikian pula, tuntutan terbesar terhadap pemerintah Indonesia adalah bagaimana pemerintah mampu merekrut guru-guru baru dengan strategi baru yang tentunya mengikuti perkembangan dan tuntutan abad 21. Calon-calon guru yang mampu berpikir kritis, kompeten dalam memecahkan masalah, kreatif-inovatif, komunikatif, menguasai ilmu pengetahuan, menguasai multi bahasa dan menguasai ICT, didukung dengan kompetensi kepribadian, emosional dan spiritual yang stabil, seharusnya yang menjadi prioritas (Darma, 2009). 
Model pendidikan yang berbasis keterampilan abad 21 atau Four Cs Competences mencakup: komunikasi, kolaboarasi, berpikir kritis, kreatif dan inovatif (Higgins, 2008).

\section{C1. Komunikasi}

Komunikasi adalah kunci sukses dalam posisi apapun. Jika komunikasi seseorang itu baik, menggunakan bahasa yang komunikatif sehingga dapat dipahami oleh semua orang, bisa meyakinkan para penerima, pesannya singkat, jelas dan sesuai dengan target yang diharapkan, maka semua pesan akan tersampaikan dan akan mempengaruhi penerima untuk mengikuti atau setidaknya tidak melakukan penolakan terhadap informasi tersebut. Dalam bisnis atau profesi apapun, komunikasi merupakan salah satu bagian yang sangat vital. Komunikasi adalah proses penyampaian informasi atau suatu pemahaman umum dari seseorang terhadap orang lain (Lunenburg, 2010).

Sekolah atau perguruan tinggi berkewajiban melatih keterampilan komunikasi para siswa dan mahasiswanya, agar mampu berkomunikasi dengan baik, bisa diterima di pasar kerja, dan mampu mendorong serta meningkatkan bisnis perusahaan atau institusi tempat mereka berkarir. Akan tetapi, kompetensi komunikasi ini juga tidak ada mata pelajarannya di sekolah, atau juga tidak ada mata kuliahnya, selain pada program studi ilmu komunikasi. Keterampilan ini menjadi sangat penting bagi semua siswa dan mahasiswa dari program studi apapun, karena semua mereka akan berkarya dan berperan di masyarakat dan kompetensi komunikasi akan mereka gunakan dalam melaksanakan karir mereka secara profesional. Oleh karena itu, pembinaan kompetensi komunikasi juga menjadi mandat dalam proses pembelajaran pada semua mata pelajaran dan mata kuliah.

Keterampilan yang harus dilatihkan pada semua peserta didik dalam proses pembelajaran adalah sebagai berikut: 1) Mengartikulasikan pemikiran dan gagasan dengan jelas, simpel dan mudah dipahami, baik dalam bahasa lisan, tulisan atau komunikasi nonverbal lainnya; 2) Mendengarkan uraian yang disampaikan penyampai pesan, apapun isi pesan tersebut, apakah pengetahuan baru, nilai-nilai baru, sikap-sikap baru, atau pesan-pesan lain untuk dikerjakan bersama. 3) Menggunakan komunikasi untuk berbagai tujuan, apakah untuk penyampaian kabar, instruksi/perintah, memotivasi, meyakinkan seseorang untuk mengikuti pemikirannya, atau mempengaruhi seseorang; 4) Melatih penggunaan berbagai media 
komunikasi berbasis teknologi terbaru; 5) Melatih komunikasi dalam konteks sosial berbeda dengan menggunakan pendekatan budaya dan bahasa yang berbeda. Para siswa dan mahasiswa harus dilatih untuk komunikasi dengan multilingual channel, serta pendekatan multi budaya dengan sikap multicultural (Roekel, 2012).

\section{C2. Kolaborasi}

Kolaborasi tiada lain adalah kerjasama dengan melakukan pertukaran informasi, mengembangkan berbagai pilihan kegiatan dan pekerjaan bersama, melakukan sharing sumber daya, meningkatkan kapasitas dari masing-masing organisasi untuk mencapai tujuan bersama, dan dikembangkan melalui jejaring kerja, koordinasi dan kooperasi antar institusi, organisasi dan korporasi dalam melaksanakan sebuah pekerjaan. Himmelman menyatakan bahwa ada tiga komponen penting dalam kolaborasi, yaitu: jejaring kerja, koordinasi dan kerjasama (Himmelman, 2002).

Jejaring kerja adalah mengembangkan jejaring dengan sesama mitra kerja untuk bertukar informasi dan melakukan kerjasama yang saling menguntungkan. Jejaring kerja itu bisa dilakukan antar instansi dalam satu kota yang sama, antar kota, provinsi dan bahkan antar negara dan bangsa, yang dilakukan untuk bisa saling memahami satu sama lain, serta dapat melakukan langkah-langkah kongkrit untuk mengembangkan kolaborasi di antara mereka, dalam rangka melaksanakan sebuah proyek, pekerjaan dan kegiatan bisnis untuk mencapai tujuan dan keuntungan bersama.

Bersamaan dengan pengembangan jejaring kerja adalah koordinasi, yakni melakukan pertukaran informasi, mengembangkan alternatif kegiatan yang akan dikerjakan bersama, dimulai dari penyamaan persepsi, menentukan langkah dan tindakan, kemudian menentukan tindakan atau aksi-aksi bisnis yang dapat membawa keuntungan bersama antar seluruh pihak yang terlibat dalam kerjasama, dan konsisten dalam mengikuti langkah-langkah untuk mencapai tujuan bersama. Koordinasi memerlukan keterlibatan organisational yang lebih dalam dari sekedar jejaring, karena sudah harus melibatkan banyak sumber daya yang diperlukan dalam bekerja. Oleh sebab itu, dalam koordinasi hubungan organisasi sudah jauh lebih bersahabat satu sama lain, dan seluruh penghalang komunikasi dikurangi dan bahkan dieliminasi, sudah banyak waktu dialokasikan dan sudah lebih saling percaya antara satu dengan lain. 
Sementara cooperation atau kerjasama adalah pertukaran informasi, mengembangkan pilihan-pilihan aksi dalam kegiatan bisnis organisasi, melakukan pembagian sumber daya yang saling menguntungkan untuk mencapai tujuan bersama. Keterlibatan masingmasing organisasi dalam kerjasama sudah semakin besar, masingmasing harus membagi SDM, keuangan, teknologi, staf, properti, akses pada sumber daya manusia dalam organisasi, dan bahkan alatalat dari masing-masing organisasi. pada level ini, sebaiknya kolaborasi sudah dilengkapi dengan perjanjian teknis tertulis sehingga masing-masing memiliki dasar legal dalam pemanfaatan semua sumber daya organisasi. Dalam kerjasama, dedikasi waktu dari masing-masing organisasi sudah semakin besar, kepercayaan harus sudah meningkat bahkan diikat dengan Perjanjian Kerja Sama (PKS), dan bahkan akses informasi, SDM dan properti harus dibuka sesuai perjanjian.

Itulah hakikat kolaborasi yang merupakan model bisnis di era milenia, bahkan dalam kolaborasi diharapkan masing-masing organisasi memberikan dedikasinya yang terbaik, mengalokasikan waktu yang banyak sesuai keperluan proyek, saling percaya satu sama lain dan mengembangkan bisnis yang saling menguntungkan agar bisa survive and sustainable. Dalam kolaborasi, masing-masing organisasi ikut bertanggung jawab terhadap kemajuan, kemunduran dan risiko dalam setiap pekerjaan, semua dilakukan bersama untuk mencapai tujuan bersama, sebagaimana mereka juga share dalam penghasilan, pendapatan dan bahkan bonus pekerjaan secara fair.

Berbeda dengan dua kompetensi critical thinking dan komunikasi, kompetensi kolaborasi memerlukan bantuan kurikulum tertulis dalam pembelajaran, dan dapat dimasukkan pada mata pelajaran Ilmu Pengetahuan Sosial, Pendidikan Pancasila dan Kewarganegaraan, dan Bahasa Inggris, dilakukan secara interseksional, yakni semuanya terintegrasi dalam kesatuan program, tetapi menyebar dalam beberapa mata pelajaran. Dalam mata pelajaran IPS menyebar pada geografi, ekonomi, sosiologi dan sejarah. Untuk Pendidikan Pancasila dan Kewarganegaraan, lebih pada penekanan kesadaran akan pentingnya menjaga patriotisme di tengah-tengah dorongan diaspora, sementara bahasa Inggris lebih pada keterampilan bernegosiasi dan mempengaruhi orang lain. Meskipun demikian, kolaborasi juga bisa dilatihkan dalam proses pembelajaran melalui teknik Problem Based Learning (PBL) dan Project Based Learning 
dalam IPA, IPS atau Pendidikan Agama, umpamanya ketika memasuki pokok bahasan yang relevan.

\section{C3. Berpikir Kritis}

Critical thinking atau berpikir kritis yang dipengaruhi oleh dua cara pandang yaitu secara filosofis dan psikologis. Menurut cara pertama, berpikir kritis diartikan sebagai cara berpikir yang bertujuan, berbasis regulasi, teori, konsep, dan hasil analisis terhadap data, serta menggunakan berbagai kriteria yang jelas dan terukur. Inilah pendekatan filosofis untuk mengidentifikasi critical thinking, yang sedikitpun tidak menyinggung soal common sense, justru dalam pendekatan filosofis menuntut tagihan-tagihan teori, konsep dan regulasi, serta prosedur analisis yang metodologis berbasis data empirik. Pendekatan filosofis melihat pada kebenaraan proses dan prosedur, serta integritas berfikir yang disandarkan pada teori dan regulasi. Sementara dalam pandangan secara psikologis, critical thinking sering dimaknai dengan penggunaan keterampilan atau strategi kognitif untuk meningkatkan probabililitas pencapaian outcome yang diharapkan (Lai, 2011).

Dengan demikian, untuk berpikir kritis tidak cukup hanya mampu berpikir berbeda dengan kebijakan publik, keputusan pimpinan institusi, tapi justru adalah berfikir konstruktif untuk membawa perubahan terhadaap keadaan yang diasumsikan akan merugikan institusi karena pelambatan atau karena prosedurnya yang keliru berdasarkan regulasi, teori atau konsep. Kemudian, critical thinking juga memerlukan metodologi berpikir yang sainstifik, berbasis data, teori, regulasi dan konsep, serta analisis obyektif dengan teknik dan metode yang bisa dipertanggung jawabkan. Keterampilan itu yang harus dilatihkan pada para siswa dan mahasiswa dalam keseluruhan proses pembelajaran yang dilakukan, karena secara spesifik, tidak ada mata pelajarannya atau mata kuliahnya dan tidak ada waktu khusus untuk melatih mereka, akan tetapi menjadi kunci sukses mereka sebagai profesional, dan kunci sukses dunia untuk merajut peradaban di masa yang akan datang. Oleh karena itu, critical thinking dimasukkan dalam salah satu agenda strategis melatih para siswa dan mahasiswa melalui proses pembelajaran, dan menyatu pada semua mata pelajaran, matematika, sains, sosial dan bahasa.

Sejalan dengan itu, Roekel menjelaskan bahwa setidaknya ada empat kompetensi dasar yang harus dimiliki oleh para perserta didik, baik siswa maupun mahasiswa agar memiliki kompetensi critical 
thinking yang baik, yaitu: mampu menyampaikan argumentasi logis secara efektif, mampu berfikir sistemik, mampu merumuskan kesimpulan, dan mampu melakukan pemecahan masalah atau problem solving secara efektif (Roekel, 2012). Secara rinci diuraikan sebagai berikut.

1. Kemampuan memformulasi pemikiran secara rasional baik logika deduktif ataupun induktif yang sesuai dengan kebutuhan formulasi penyelesaian masalah atau mempersepsi suatu usulan. Analisis dapat dimulai dengan teori, regulasi, atau idealitas, dan dielaborasikan secara lebih detail, kemudian mengemukakan data, fakta atau kenyataan empirik. Selanjutnya, menganalisis kesenjangan antara regulasi dengan implementasi, antara idealitas dengan realitas dan seterusnya, sehingga dapat diformulasikan masalahnya. Itulah cara berpikir deduktif. Akan tetapi, jika berpikir induktif, dimulai dengan berbagai kenyataan, lalu disandingkan dengan regulasi, teori atau harapan, dan kemudian dianalisis kesenjangannya agar dapat diformulasikan permasalahannya.

2. Kemampuan menjaga koherensi fakta antara satu dengan yang lain, dan mampu mensinergikan fakta-fakta tersebut, sehingga menjadi satu kesatuan, untuk dianalisis langkah-langkah penyelesaian masalahnya, atau langkah-langkah pembaharuan yang akan dikembangkan atau apapun idenya. Dengan demikian, peserta didik mampu menjaga hubungan dialektika antara satu fakta dengan lainnya, dan antara fakta dengan masalah, dan antara masalah dengan solusinya.

3. Kemampuan merumuskan kesimpulan yang diawali dengan pengumpulan data yang sesuai, menganalisis data, lalu merumuskan kesimpulan berbasis data dan didukung dengan teori, serta menyesuaikan kesimpulan tersebut pada regulasi, teori atau konsep, dan menjaga konsistensi analisis masalah dengan argumentasi yang melatarbelakangi masalah tersebut.

4. Semua siswa dan mahasiswa harus dilatih untuk mampu menyelesaikan masalah, yakni bahwa kesimpulan tersebut mampu menjawab permasalahan yang sedang dihadapi institusi, dan pemikiran tersebut merupakan salah satu solusi menyelesaikan permasalahan institusinya, baik dalam aspek SDM, keuangan, infrastruktur, maupun kemajuan perusahaan, institusi atau 
korporasi agar bisa jauh lebih baik dari yang sudah berkembang saat itu.

Kompetensi-kompetensi tersebut harus diperoleh oleh setiap siswa dan mahasiswa agar mereka bisa memasuki pasar kerja global, baik pada tingkat ASEAN, APEC, maupun pada tingkat global yang akan terus bergerak seiring dengan perkembangan yang cepat dari teknologi informasi, sehingga dunia menjadi borderless, dan mobilitas manusia di dunia bukan antar kota dalam sebuah negara, akan tetapi antar negara di dunia. Kompetensi-kompetensi ini tidak ada mata pelajaran atau mata kuliah yang megajarkannya secara spesifik, tidak ada paket pelatihannya, dan hal ini menjadi mandat guru yang harus dilatihkan pada semua peserta didik dalam proses pembelajaran sains, matematika, IPS dan bahasa di dalam kelas. Oleh sebab itu, maka kini dikembangkan multiliteracy pedagogy, agar para guru memiliki integritas untuk menjadikan mata pelajarannya sebagai wahana berlatih critical thinking.

\section{C4. Berpikir Kreatif dan Inovatif}

Ada yang berpendapat bahwa kreativitas adalah bawaan dari lahir setiap manusia atau sesuatu yang dilahirkan. Jika mengacu pada pendapat ini, maka hanya sedikit saja orang kreatif di dunia ini. Akan tetapi para ahli pendidikan, tidak sepakat dengan pandangan tersebut, sehingga mereka merancang bagaimana mempersiapkan anak-anak bangsa menjadi kreatif melalui proses pendidikan. Kreatif itu sendiri bermakna kemampuan untuk melahirkan suatu gagasan, konsep baru untuk menyelesaikan suatu masalah, atau kemampuan menciptakan prototype untuk melahirkan sebuah produk baru yang akan dihasilkan (Fadaee \& Alzahrh, 2014). Pengertian di atas, setidaknya menyiratkan empat kriteria untuk seseorang dikatakan sebagai seorang kreatif, yakni: 1) Kemampuan berfikir divergen yang bisa memberikan solusi berbeda dari yang lain tentang sebuah masalah; 2) Memiliki ilmu yang cukup dan memiliki pengalaman masa lalu yang relevan; 3) Memiliki kemampuan untuk berkomunikasi sehingga bisa bertukar informasi dengan koleganya; dan 4) Memiliki kapasitas dalam berfikir kritis dan memiliki kemampuan analisis yang baik.

Untuk menghasilkan anak kreatif diperlukan lingkungan yang mendukung, pelatih yang memiliki kompetensi, pelatihan yang cukup, dan individual yang pekerja keras, sehingga makna kreatifitas kini sudah tidak diperdebatkan lagi, bahwa kreatifitas itu dibentuk bukan dilahirkan. Kreatifitas selalu berdampingan dengan inovasi, karena 
keduanya memiliki persamaan, bahwa kreatifitas menuntut adanya pemikiran atau gagasan baru untuk penyelesaian masalah. Kreatifitas juga terkait dengan prototype dan produk baru sebagai alternatif untuk memperbaiki produk yang sudah ada. Dengan demikian, dalam proses berfikir kreatif terdapat fase melahirkan sebuah formula baru, dan ada proses implementasi formula tersebut untuk bisa dipakai dalam penyelesaian masalah. Oleh karena itu, orang kreatif bukan orang yang hanya berfikir imajinatif, tapi yang menggunakan hasil pemikirannya untuk menyelesaikan masalah, bukan untuk melahirkan masalah.

Demikian pula halnya dengan inovasi, sebagaimana diartikan Rogers (1998) bahwa inovasi adalah sesuatu yang benar-benar baru dan benar-benar ada pengembangan yang signifikan dikerjakan oleh perusahaan untuk melahirkan nilai tambah baik bagi perusahaan maupun bagi pengguna produk. Dalam inovasi selalu dituntut ada proses kreatif, hanya fokusnya adalah nilai tambah, baik bagi perusahaan atau institusi maupun bagi para pemakai. Sementara proses kreatifitas biasanya diorientasikan untuk melahirkan formula baru dalam rangka menyelesaikan masalah. Akan tetapi, Fadaee dan Alzahrh (2014) dengan mudah membedakan bahwa kreatiftas itu adalah proses melahirkan ide baru, gagasan baru, formula baru dan model baru, sementara inovasi adalah cara baru dalam mengoperasikan formula baru tersebut. Dengan demikian, inovasi selalu hadir setelah karya-karya kreatif diciptakan. Akan tetapi, kreatifitas tidak akan diakui sebagai sebuah karya kreatif jika belum ada bukti produk baru dan model baru yang benar-benar distingtif dan membawa perubahan, sehingga terdapat pula definisi kreatifitas itu adalah bringing imagination into being (Fadaee \& Alzahrh, 2014).

Kesimpulan ini sejalan dengan teori yang dikembangkan oleh Roekel, menurutnya hubungan antara kreatifitas dan inovasi terdiri dari tiga tahap, yaitu: berpikir kreatif, bekerja kreatif dan melaksanakan pekerjaan dengan inovasi baru (Roekel, 2012). Adapun Penjelasan Ketiga tahap tersebut adalah sebagai berikut.

1. Berpikir kreatif, yakni melatih para siswa dan mahasiswa untuk brainstorming supaya memperoleh ide dan masukan yang sangat luas. Kemudian merumuskan ide, baik ide incremental, yakni ide kreatif mengikuti arus, maupun radikal, yakni ide kreatif melawan arus. an terakhir mengelaborasi, menganalisis dan 
mengevaluasi ide-ide yang sudah dirumuskan untuk dikembangkan secara lebih luas dengan upaya yang maksimal.

2. Bekerja kreatif, yakni melatih para siswa dan mahasiwa untuk mengembangkan, melaksanakan, mengkomunikasikan ide-ide baru pada orang lain. Kemudian terbuka dengan masukan-masukan, demonstrasikan ide-ide baru dalam pelaksanaan pekerjaan, dan perhatikan kekurangan-kekurangannya untuk diperbaiki kemudian.

3. Laksanakan inovasi, yakni implementasikan ide-ide baru dengan cara baru dan pastikan bahwa cara-cara baru tersebut akan membawa kebaikan bagi institusi atau bagi para pelanggan aau pengguna jasa.

Sebagaimana pada kompetensi critical thinking dan komunikasi, kompetensi kreatifitas dan inovasi juga harus dilatihkan pada para siswa dan mahasiswa baik di dalam kelas dan di luar kelas. Pelatihan kedua kompetensi dasar tersebut dapat dilakukan dengan Problem Based Learning (PBL) pada mata pelajaran yang relevan apakah dalam IPA, IPS, matematika, Pendidikan Pancasila, Kewarganegaraan, dan Pendidikan Agama, atau bahkan olah raga. Pelatihan kedua kompetensi dasar tersebut tidak difasilitasi dengan pokok bahasan pada mata pelajaran atau mata kuliah tertentu. Akan tetapi, dimasukkan dalam konten pembelajaran melalui prosedur pelaksanaan tugas, baik mencari data, menganalisis data, menyimpulkan, dan mempresentasikan temuan atau hasil dan membahasnya serta menyampaikan kesimpulan hasil belajar mereka.

\section{Kesimpulan dan Implikasi}

Berdasarkan temuan penelitian ini dapat ditarik beberapa kesimpulan, yaitu: 1) lebih dari $90 \%$ partisipan memiliki persepsi positif terhadap model pendidikan Islam yang berbasis keterampilan abad 21;2) keberhasilan penerapan model pendidikan Islam berbasis keterampilan abad 21 sangat ditentukan oleh fasilitas pendukung dan kompetensi para pendidik; dan 3) upaya-upaya yang dilakukan oleh partisipan sebagai bagian dari generasi milenial untuk menguasai keterampilan abad 21 adalah belajar bersungguh-sungguh dengan meningkatkan pemahaman terhadap ilmu pengetahuan dan temuantemuan baru dalam bidang teknologi dan berusaha untuk menggunakan teknologi secara cerdas untuk membantu menyelesaikan tugas-tugas kuliah, melibatkan diri dalam berbagai kegiatan organisasi baik di dalam maupun di luar kampus untuk 
mengasah keterampilan komunikasi dan kolaborasi, serta berupaya aktif melakukan penelitian untuk mengasah kompetensi berfikir kritis, kreatif, inovatif dan pemecahan masalah.

Penelitian ini merekomendasikan kepada para pendidik agar meningkatkan kompetensinya dalam merancang pembelajaran dengan menggunakan berbagai metode, pendekatan, dan strategi serta variasi kegiatan yang dapat melatih dan mengasah keterampilan abad 21 . Lembaga-lembaga pendidikan perlu memenuhi fasilitas penunjang penguasaan terhadap keterampilan abad 21, ketersediaan perangkat teknologi seperti komputer dan jaringan internet yang memadai. Kepada generasi milenial agar senantiasa aktif dalam berbagai kegiatan-kegiatan ilmiah baik di dalam maupun di luar kampus dan menggunakan waktu dan kesempatan secara efektif, efisien dan produktif serta menimba ilmu dan pengalaman yang bermanfaat seluas-luasnya. 


\section{Daftar Pustaka}

Brown, John Seely. (2005). Learning in a Digital Age, dalam Learning in the 21st Century, Teaching Todays Students on Their Terms, International Education Advisory Board.

Center, P. R. (2010). Millennials: A portrait of generation next. Confident, Connected, Open to Change. Washington.

Darma, Surya. (2008). Pembangunan Pendidik dan Tenaga Kependidikan Abad 21. Makalah disajikan pada Kuliah Umum Program Pascasarjana Universitas Negeri Malang.

Eggen, Paul dan Kauchack, Don. (2004). Educational Psychology: Windows on Classrooms. International Edition. New Jersey: Pearson Education, Inc.

Fadaee, Akbar., dan Haitham Obaid Abd Alzahrh. (2014). Explaining the Relationship between Creativity, Innovation and Entrepreneurship. International Journal of Economy, Management and Social Sciences, Vol 3, No 12, December.

Fajrina, Hani Nur. (2016). Akses Internet Minim, Indonesia Lebih Aktif di Media Sosial. CNN Indonesia, Rabu, 28/09/2016. Diakses 20 Desember 2018.

Hanna, Herianti, Tasrim, I.W, dan Risky. N. (2019). The Principal Leadership Based on Higher Order Thinking Skills for Realizing $21^{\text {st }}$ Century Education. International Journal of Science and Research. Vol. 8 Issue 1, hal. 839-846.

Higgins, Meagen. R. (2008). The $21^{\text {st }}$ Century Learning Skills: Global Learning in an Urban Middle School. Thesis. The Graduate School of Wichita State University. Diunduh pada 24 Desember 2018.

Himmelman, Arthur T. (2002). Collaboration For A Change, Definitions, Decision-making models, Roles, and Collaboration Process Guide, HIMMELMAN Consulting Minneapolis, USA.

Joyce, Bruce dan Weil, Marsha. (1980). Models of Teaching. Second Edition. Englewood Cliffs, New Jersey: Prentice-Hall, Inc.

Jukes, Ian. (2005). Understanding Digital Kids:Teaching and Learning in the New Digital Landscape, Learning in the21st Century, Teaching Today Students on Their Terms. International Education Advisory Board. 
Lunenburg, Fred C. (2010). Communication: The Process, Barriers, And Improving Effectiveness. Schooling Volume 1 Number 1, Sam Houston State University, USA.

Lai, Emiliy, R. (2011). Critical Thinking: A Literature Review, Research Report, Pearson.

McGovern, Gerry. (2017). Millenial Attitude. https://medium.com/@gerrymcgovern/millennial-attitude846fec2a4aba. Diakses tanggal 07 Desember 2018

Miles, M. B. dan Huberman, A. M. (1994). Qualitative Data Analysis: an Expanded Sourcebook. Thousand Oaks, CA: Sage.

Muslih, A., Sunarno, W., \& Aminah, N.S. (2013). Pembelajaran Berbasis ICT Religi Model Animasi untuk Meningkatkan Karakter dan Prestasi Belajar Listrik Dinamis pada Peserta Didik SMA Negeri 8 Surakarta. Jurnal Inkuiri.Vol.2 No.3 hal. 302-311. http://jurnal.fkip.uns.ac.id/index.php/sains

Nata, A. tanpa tahun. Pendidikan Islam di Era Milenial. Hasil Penelitian Guru Besar Ilmu Pendidikan Islam Fakultas Tarbiyah dan Keguruan UIN Syarif Hidayatullah, Jakarta. Conciencia Jurnal Pendidikan Islam.

Nistanto, Reska K. (2015). Kebiasaan Orang Indonesia, Pelototi "Smartphone" 5,5 Jam Sehari, Kompas Tekno, Jumat, 4 September 2015.

Patimah, L. (2017). Redesain Pembelajaran Pendidikan Islam dalam Perspektif Pembelajaran Abad 21. Jurnal Pendidikan Sekolah Dasar (JPSD) Vol.2 No.2.

Robinson, Sharon P., \& Ken Kay. (2010). 21st Century Knowledge and Skills in Educator Preparation, Partnership for Twenty first Century Skill, American Association of Colleges of Teacher Education.

Roekel, Dennis Van. (2012). Preparing 21st Century Students for a Global Society, an Educator Guide to the Four Cs. National Education Association, USA.

Rogers, Mark. (1998). The Definition and Measurement of Innovation, Melbourne Institute of Applied Economic and Social Science, the University of Melbourne.

Sofwan, M., \& Habibi, A. (2016). Problematika dunia pendidikan Islam abad 21 dan tantangan pondok pesantren di Jambi. Jurnal Kependidikan: Penelitian Inovasi Pembelajaran, 46(2), 271-280. 
Sudibyo, E., Jatmiko, B., \& Widodo, W. (2016). The Effectiveness of CBL Model to Improve Analytical Thinking Skills the Students of Sport Science. International Education Studies, 9(4), 195-203.

Sugiyono. (2014). Metode Penelitian Managemen. Bandung: Penerbit Alfabeta.

Suyono \& Hariyanto. (2012). Belajar dan Pembelajaran. Bandung: PT. Remaja Rosdakarya.

Tilaar, H. A. R. (2006). Standarisasi Pendidikan Nasional: Suatu Tinjauan Kritis. Jakarta: Rineka Cipta.

Tilaar, H. A. R. (1997). Pengembangan Sumber Daya Manusia dalam Era Globalisasi: Visi, Misi dan Program Aksi Pendidikan dan Pelatihan menuju 2020. Jakarta: Grasindo. 